\title{
Motion graphics as first aid information medium for early childhood diseases
}

\author{
Z.V. Rahmallah \& Y. Rahman \\ Telkom University, Bandung, Indonesia
}

\begin{abstract}
Parents are the first doctors for their children, so it is essential that they know about children's health in general. In this regard, there is much information available on the internet displayed in the forms of text, audio, video, and other media such as animation. This study aimed to optimize motion graphics, a form of video, as a first-aid informational tool for dealing with a variety of illnesses that children might develop. The methods used in this study were observation, literature review, interviews, questionnaires, and matrix analysis. These motion graphics contain information about various types of children's illnesses including how to provide the optimal first aid which will be disseminated through social media so parents can more easily learn about it through their gadgets.
\end{abstract}

Keywords: animation, childhood, diseases, first aid, motion graphics, social media

\section{INTRODUCTION}

Along with current conditions, parents typically tend to have dual roles, especially those living in big cities: acting as parents who take care of their children and workers who support the family. At home, parents play a role as the first doctor for their children. Therefore, it is crucial for parents to have basic technical knowledge and understanding of children's health, especially about illnesses that are often faced by children at a young age, such as fever, cough, flu, vomiting, asthma, diarrhea, etc. Without this knowledge, parents will most likely panic when their children suffer from one of these illnesses.

In this era of internet access, it is very easy to get information about anything, including health. Some of them are presented with text, others are presented through audio and video. As Edgar Dale said in the Cone of Experience in Sari (2019), if the information is presented in a visual form, then the possibility of remembering will be greater than that which is only presented in the form of text. Mayer and Moreno in Sukiyasa and Sukoco (2013) said that animation can improve memory absorption if used consistently by the cognitive principles of multimedia learning. Multimedia and technology can be sources that help teachers to facilitate student learning, and motion graphics animation is one such form (Amali et al. 2020). In this context, motion graphics can be a medium for conveying information about various types of illnesses and first aid that can be done by parents at home.

\section{RESEARCH METHODS}

This study was developed through literature review on instructional media, interviews with medical experts and motion graphic designers, observations at home and hospitals, and observations on interactions with motion graphics that contain educational context. 


\subsection{Literature review}

According to Nazir in Miranti et al. (2017), a literature study is not done just to look for secondary data to support the research, but also to understand how far the relevant knowledge we have goes and conclude what further is needed. In a multimedia context, Lancien in Surasmi (2016) said that multimedia in this era refers to the incorporation and integration of media, such as text, animation, graphics, sound, and video into a computer system. The illustrations used in multimedia can communicate messages in a better way.

In a similar opinion, Whardani argues that motion graphics are graphs that use video or animation to create the illusion of movement or transformation. Motion graphics can help simplify messages from content carried out by databases by using interesting ways to present information (Miranti et al. 2017). For this reason, according to Miarso, it is important to create well-designed and attractive visual media to stimulate internal dialogue in students, in other words, communication between students and the media or between students and message sources. For example, the instructor is said to be successful if there is an improvement in the student (Agustina 2015).

One of the most popular and easy-to-understand media across generations is animation because it is one of the most interesting forms of illustrative representation that illustrates the movement of an object. Animation in the learning process can help raise the effectiveness and efficiency of the learning process and boost study results. Besides that, it can also raise a student's desire and motivation to keep up with the learning process (Sukiyasa \& Sukoco 2013).

In the context of the learning process, Dale said that when someone studies, the results obtained by firsthand experience are concrete. They are as real as things that happened in someone's environment, replicas of something, and verbal symbols (abstract). Getting up to the top of the cone, the media of message delivery is becoming more abstract. The learning process and teaching interaction doesn't need first-hand experience anymore; they can start from the type of experience that is most appropriate with the student's skills and depends on the learning situation (Sari 2019).

\subsection{Interview and observation}

Interviews were performed with medical experts and motion graphic designers. It aimed to get insights and explanations from the experts. According to the experts' interviews, parents need to learn about first aid information for young children because they are their children's first guardians. Experts have explained the kind of illnesses that are more likely to happen to children and how to give them first aid for each illness. The next step was observations done in the hospital to get information about the effective steps to treat those diseases.

\subsection{Matrix analysis}

Matrix analysis was made to measure and find the best elements from comparing several references, because according to Rohidi 2011 in Miranti et al. 2017, matrix analysis is the best tool for managing information or analyzing objects. Matrix analysis is a column and row which is shown in two different dimensions, a concept or data reference to identify the data's similarities and differences in that research (Miranti et al. 2017). In this study, two motion graphics videos were compared in terms of duration, final resolution, color nuances, movement patterns, voice-over, information displayed, and effects used. Then, the right elements were taken to be displayed for the target audience who are young parents that are active in social media. These elements were then used as the main reference in making motion graphics, with the theme of first aid for children.

\section{RESULT AND DISCUSSION}

Visual media can help us in the learning process. One such medium is motion graphics that can be used to present information in an interesting way for a short time. According to observations and 
interviews, motion graphics with simple and informative concepts are suitable for young parents to obtain information and knowledge about children's health, as well as how to do the proper first aid effectively.

The illustration reference that will be used is a simple line art illustration style with shades of peach and yellow, adjusted to the colors of femininity. Flower-themed graphics will also be used in this video to raise the female-oriented character. The character used in this motion graphic is a young woman, to represent young parents. This character will present information in an interesting way in a short time.

\subsection{The message}

The message expected to convey in this work is information about the types of diseases that are often hit children and how to do the right first aid. The main goal is to keep the child safe with the right help.

\subsection{Creative concept}

Based on the data that has been obtained, the main viewers of this motion graphic are women, so the creative concept exhibits femininity, calmness, and intelligence, to convey the impression of a flexible, gentle, and intelligent woman.

\subsection{Visual concept}

The visual concept that was used in this motion graphic will be divided into soft nuances of typography, with a yellow and peach color palette. Graphic elements such as red and yellow flowers, and character designs that feature figures, that have been described in creative concepts, also used.

\subsection{Media concept}

These motion graphic viewers are parents who have toddlers. According to the data already obtained, parents often use the internet as a source of information. Therefore, the media that were used to spread the motion design was a platform on the internet that is often seen by these parents, especially Instagram and YouTube.

\subsection{Final art work (artwork)}

The main typography used for the title has a dynamic character and is shaped like handwriting, to strengthen the impression of womanhood, and to be more familiar to first-time viewers.

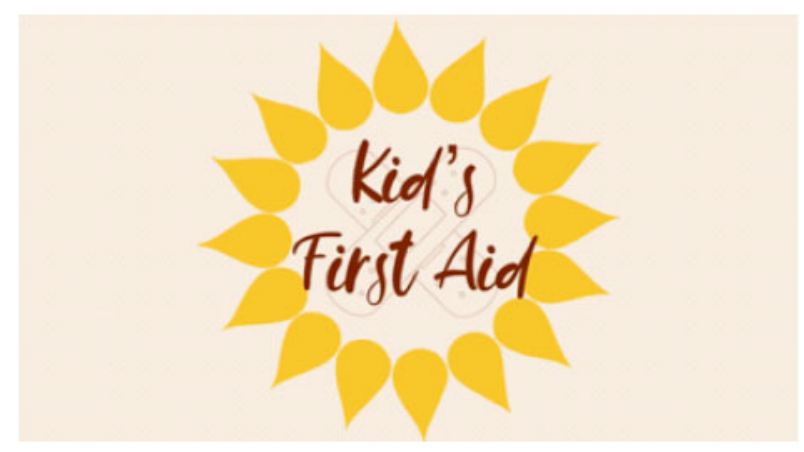

Figure 1. Typography in title design. 
The color spectrum used is warm shades, such as yellow, peach, pink, and red brick. These colors are also implemented in the colors of the figure which represent a graceful and intelligent woman. This color depicts the warmth of parents who care for and love their children.

As a result, portrayals of the figure explaining various children's illnesses and how they are treated are displayed as simply as possible so that information is focused and reaches the audience quickly. The duration used is also quite proportional, between 30-60 minutes, depending on the medium.
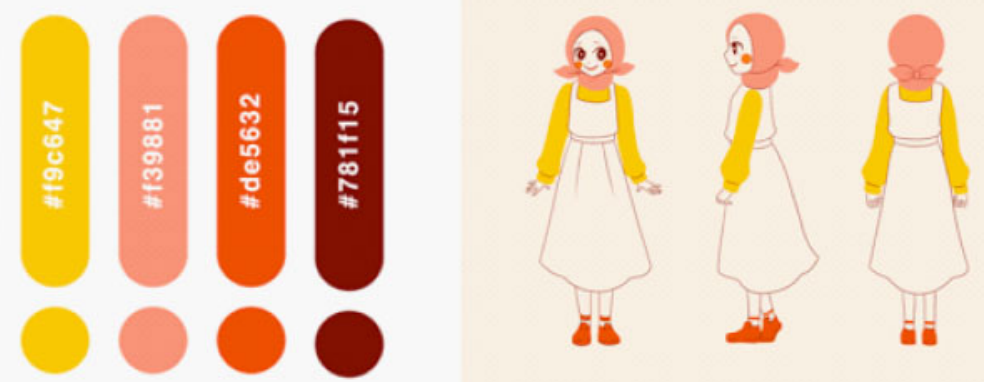

Figure 2. Color implementation in the design.

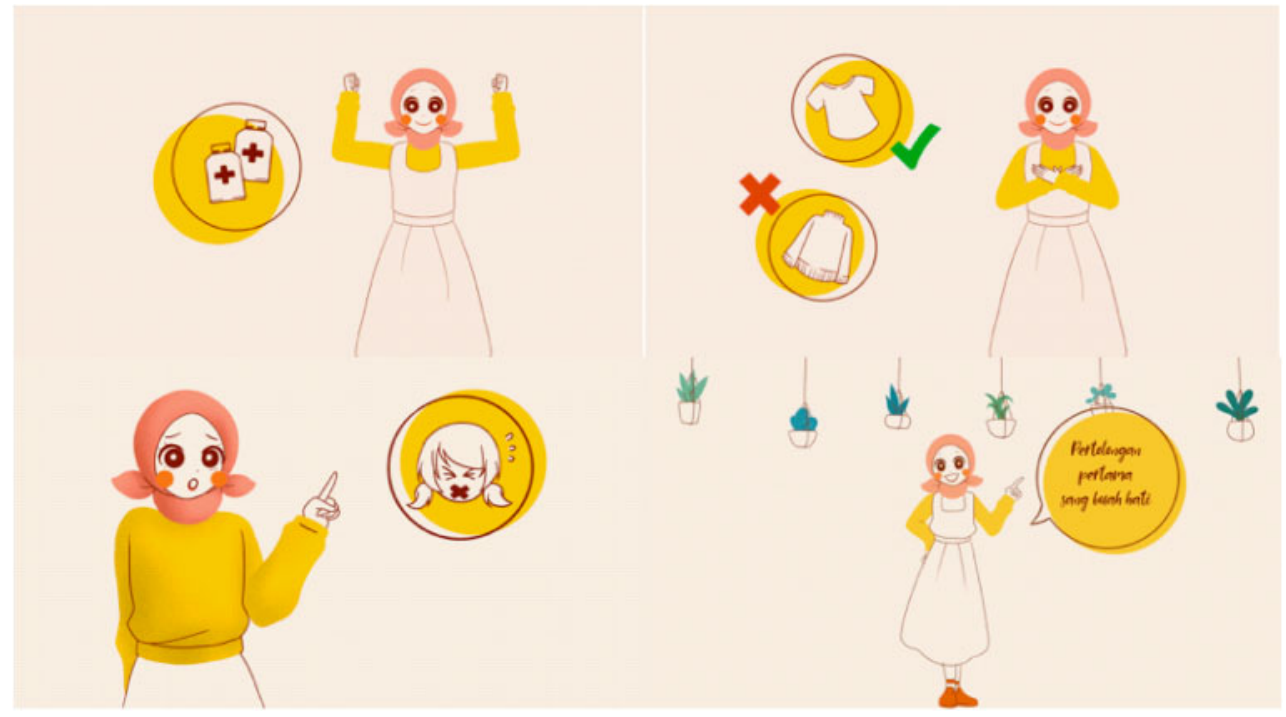

Figure 3. Motion graphic scene.

\section{CONCLUSION}

Based on observations, suggestions, and input after the post-test to the audience, it is concluded that motion graphics videos can be used to relay information on first aid for young children's diseases effectively. However, there was a suggestion of adding some more descriptive illustrations to make the information clearer and easier to understand quickly. Other functions of this motion graphic are 
also expected to help parents have a better understanding of various types of children's illnesses and make them more able to inform others about the knowledge of these illnesses.

\section{ACKNOWLEDGEMENTS}

We would like to thank all those who were involved in supporting this research: resource personnel, collaborators, audiences, reviewers, mentors, and several others who cannot be mentioned. This research still has the potential to be developed in different contexts, and for a wider audience. Hopefully, this research can be useful for many people.

\section{REFERENCES}

Agustina, L. 2015. Pengaruh Penggunaan Media Visual dan Minat Belajar Siswa terhadap Hasil Belajar Matematika. Formatif: Jurnal Ilmiah Pendidikan MIPA 1(3). doi: 10.30998/formatif.vli3.74.

Amali, L. N., Zees, N., and Suhada, S. 2020. Motion Graphic Animation Video as Alternative Learning Media. Jambura Journal of Informatics 2(1). doi: 10.37905/jji.v2i1.4640.

Miranti, G. D., Putra, I. D. A. D., and Komariah, S. H. 2017. Perancangan Animated Motion Graphic Sebagai Media Alternatif Pembelajaran Anak Tunagrahita. E-Proceeding of Art \& Design 4(3):634-643.

Sari, P. 2019. Analisis Terhadap Kerucut Pengalaman Edgar Dale dan Keragaman Gaya Belajar untuk Memilih Media yang Tepat dalam Pembelajaran. Mudir: Jurnal Manajemen Pendidikan 1(1):58.

Sukiyasa, K. and Sukoco, S. 2013. Pengaruh Media Animasi Terhadap Hasil Belajar dan Motivasi Belajar Siswa Materi Sistem Kelistrikan Otomotif. Jurnal Pendidikan Vokasi 3(1). doi: 10.21831/jpv.v3i1.1588.

Surasmi, W. A. 2016. Pemanfaatan Multimedia Untuk Mendukung Kualitas Pembelajaran. Temu Ilmiah Nasional Guru VIII Tahun 2016: Tantangan Profesionalisme Guru di Era Digital, 1595. Jakarta. Available at: http://repository.ut.ac.id/6555/. 